\begin{tabular}{|c|c|}
\hline$A$ & $\begin{array}{c}\text { International Journal of Current Research } \\
\text { and Academic Review }\end{array}$ \\
\hline & $\begin{array}{c}\text { ISSN: 2347-3215 (Online) Volume } 9 \text { Number } 01 \text { (January-2021) } \\
\text { Journal homepage: http://www.ijcrar.com }\end{array}$ \\
\hline
\end{tabular}

doi: https://doi.org/10.20546/ijcrar.2021.901.007

\title{
Role of Sesbania sesban (L.) Merrill for Soil Fertility Improvement in Ethiopia: A Review
}

\author{
Sissay Dessalgn* and Addisu Wolde \\ 1Department of Agroforestry, Debre Markose University, Ethiopia
}

*Corresponding author

\section{Abstract}

Most of world's agricultural land is degrading rapidly, and productions of agricultural crops are declined in Ethiopia due to land degradation and reduction of soil fertility. Growing of fertilizer trees in agricultural lands is timely and cost efficient way to enhance soil fertility parameters. Fertilizer trees are used to improve the condition of soils used for farming. They capture nitrogen from the air and put it in the soil through their roots and falling leaves. Sesbania sesban, Gliricidia, Tephrosia, and Faidherbia albida are known as fertilizer trees. Sesbania sesban is multipurpose fast-growing, perennial legume tree and $\mathrm{N}$-fixing shrub suitable as a soil quality improver. Sesbania sesban can grow as agroforestry component and alley cropping. It provides green manure and its leaves produce rich compost and this maintain soil fertility through Biological nitrogen fixation
\end{abstract}

\section{Article Info}

Accepted: 08 December 2020

Available Online: 20 January 2021

\section{Keywords}

Degradation, Fertilizer tree,

Sesbania, Soil fertility.

\section{Introduction}

Soil degradation and erosion have raised some serious problem on the productivity of agricultural lands (Gardner, 1996). Bekele (2003) stated that, most agricultural lands have been affected by degradation and these led reduction of agricultural productivity and slow down economic growth of the countries. The report of UNCCD (2015) showed that more than half $(52 \%)$ of all fertile, food-producing soils globally are now classified as degraded, many of the severely degraded.

Worldwide, Soil degradation affects 1966 million hectares of land (Lal, 2007). Average nutrient (NPK) loss is estimated at 9-58 kg per hectare per year. Soil fertility largely depends on soil organic matter content, which besides supplying nutrients, ensures good physical conditions necessary for water infiltration, supply of soil moisture, aeration and plant root development (MoFFEA, 1998). Soil degradation and declining soil fertility are the most significant constraints that affect food production in Ethiopia (Gete et al., 2010). According Gete et al., (2010) anthropogenic factors such as inappropriate land use systems, mono cropping, nutrients mining and inadequate supply of nutrients are aggravated the soil degradation and reduction of its fertility.

Soil degradation and fertility decline could have much impact on crop production and environmental protection. Both of the $\mathrm{N}$ imbalance and the $\mathrm{N}$ losses can be improved greatly, without sacrificing 
the crop yield, such as balanced and integrated use of fertilizers and organic manures, which are effective in increasing crop yields, nutrient use efficiency and minimizing environmental impacts (Aulakh, 2011).

In order to increase soil fertility in the short run, nutrients have to be added to the soil. This is often done by applying chemical fertilizers and through growing of fertilizer trees. Chemical fertilizers are expensive to purchase especially for small scale farmers (Gete et al., 2010). As a result, adoption of composting technology and growing of fertilizer trees are essential to sustain the balance of soil fertility and to ensure agricultural productivity. Agroforestry trees have great potential for improving soil fertility in areas dominated by $\mathrm{N}$ deficiency (Kwesiga et al., 1999). The main objective of this paper is focusing on role of Sesbania sesban for soil fertility Management

\section{Overview of fertilizer tree}

Fertilizer tree are trees used for soil fertility replenishment through management of nitrogen-fixing trees on farm (Mafongoya et al., 2006). Fertilizer trees have potential to provide Nitrogen in quantities sufficient to support moderate crop yields through Nitrogen inputs from biological Nitrogen fixation and retrieval of nitrate from deep soil layers and cycling of $\mathrm{N}$ from plant residues and manures (Buresh and Tian, 1998) (Table 1).

\section{Morphological description of Sesbania sesban species}

Sesbania sesban is widely distributed and cultivated throughout semi-arid and sub- humid tropical regions. This specie can able to grow on farm land, as agroforestry component, stream banks and swamp edges.it can be will survive up to an altitude of 2300 m.s.l (Ecocrop, 2010; Göhl, 1982), annual rainfall 500$2000 \mathrm{~mm}$ annual rainfall, $17^{\circ} \mathrm{C}-20^{\circ} \mathrm{C}$ average annual temperature and variety of soils (Heering et al., 1992; Cook et al., 2005).

\section{The role of Sesbania s. for soil management}

Sesbania sesban is a fast growing nitrogen- fixing leguminous tree species which has the capacity of rapid decomposition when incorporated into soil serving as a green manure (Patra et al., 2006) in alley cropping (Heering, 1995) which could bring about substantial increment in crop available nitrogen and soil organic carbon. It grows on a wide range of soils including very poor acidic sands and waterlogged soils, but responds well to improved fertility.

Sesbania s. are excellent legume green manure plants cultivated in different fields and alley cropping (Patra $e t$ al., 2006). Sesbania $s$. Is the most extensively used green manure species of Sesbania in tropical agro-forestry, occurs mainly in the humid uplands or wet environments. It has the capacity to improve and stabilize soil nitrogen through symbiotic interaction with bacteria. Its branches have been used as mulch and leaves as a green manure. It improves soil fertility in a short-term rotation fallow and is useful in combating striges weed (Orwa et al., 2009

This species has ability to grow at different ammonium concentrations soil culture and especially seedlings can tolerate ammonium concentrations up to $800 \mathrm{mg} / \mathrm{L}$ (Indieka and Odee, 2005; Dan and Brix, 2009; Dan et al., 2011). This high tolerance suggests that this plant has a potential to removal of heavy metals from soil, that is, phytoremediation of sites contaminated with heavy metals (Yang et al., 2003; Gupta et al., 2011).

\section{Sesbania s. for soil fertility improvement}

Soil fertility management practices (Hagos et al., 1999; Asefa, 2005) such as animal manure, crop residues, crop rotation, mineral fertilizer, fertilizer tree and compost are used to cope with declining soil fertility. Sesbania sesban are grown as annuals, relay intercropped between maize and other crops. The tree leaf biomass is incorporated at the end of the growing season; this is act as green manure to enhance productivity and fertility of soil (Kanyama-Phiri and Snapp, 1997). Sesbania as an agroforestry practice component, Sesbania fixed 500 to $600 \mathrm{~kg} \mathrm{~N} / \mathrm{ha} /$ year Nitrogen.

Sesbania fallows have a very deep root system and thereby effectively capture mineral nitrogen which has been leached below the crop rooting zone. This leads to a better recycling of nitrogen and reducing nutrient losses, leguminous fallows additionally enrich soil fertility through the process of biological nitrogen fixation (BNF).

\section{Nitrogen fixation capacity of Sesbania sesban}

The report of Shaheen et al., (2004) stated that Sesbania $s p$. Can fix up to $542 \mathrm{~kg} \mathrm{~N} \mathrm{ha}^{-1}$ in symbiosis with Rhizobium (nitrogen fixing bacteria). However this species fix nitrogen 500 to $600 \mathrm{~kg} \mathrm{~N} / \mathrm{ha} /$ year and is 
particularly promoted for soil fertility replenishment when the species are grown in agroforestry like improved fallow (Degefu et al., 2011). Sesbania sesban provide and fix high amount of Nitrogen, Carbon and Phosphors (NPK) compared to other crop residuals like maize Stover (Makumba et al., 2007). Sesbania sp. can accumulate nitrogen in root nodulating green manure cropping of ranges from 146-267 Kg N/hectare (Roger and Ladha, 1992). This species can able to grow as alley cropping and pruning from $\mathrm{S}$. sesban in combination with moderate amounts of $\mathrm{N}$ and $\mathrm{P}$ fertilizers (Yamoah and Getahun 1989). The nutrient and NPK content of a pot of Sesbania sesban reported by Makumba and his colleagues (2007) as showed below on table 2.

\section{Nutrient mineralization and immobilization of Sesbania sesban}

The use of N-rich tree pruning as a substitute to inorganic fertilizers has been recommended for low input farming systems in $\mathrm{N}$ deficient tropical soils (Akinnifesi et al., 1997; Ikerra et al., 1999; and Kang and Shanon, 2001). Pruning of Sesbania sesban have high rates of Nitrogen release leaves and branches (Mafongoya et al., 1998; Seneviratne et al., 1998). One use of organic amendments for soil fertility improvement relates to the ability of the organic inputs to supply nutrients for plant growth. This in turn requires decomposition and mineralization rates that match the plant demand for those nutrients.

The mineralisation of nitrogen from decomposing leaves of Sesbania demonstrated a similar pattern to the changes in dry weight, expressing a mineralization pattern well described by the exponential model.

\section{Sesbania sesban in agroforestry combination}

Planted tree fallows with leguminous trees or shrubs that accumulate $\mathrm{N}$ in the biomass through biological nitrogen fixation (BNF). Sesbania sesban are able to replenish soil $\mathrm{N}$ to the levels in which different crops is required (Kwesiga and Coe, 1994; Kwesiga et al., 1998).

In conclusion, most agricultural lands have been affected by degradation and these led reduction of agricultural productivity and slow down economic growth of the countries. Due to these degradation of lands an estimated 9-58 kg per hectare nutrient (NPK) are loss per year. Soil degradation and declining soil fertility are the most significant constraints that affect food production in Ethiopia. In order to increase soil fertility in the short run, nutrients have to be added to the soil. This is often done by applying chemical fertilizers and through growing of fertilizer trees.

\section{Declarations}

\section{Ethics approval and consent to participate}

This research was performed in accordance with the laws, guidelines, and ethical standards of Ethiopia where the review was performed.

\section{Author contribution statement}

All authors listed have significantly contributed to the development and the writing of this article.

\section{Funding statement}

This research did not receive any specific grant from funding agencies in the public, commercial, or not-forprofit sectors.

\section{Availability of data and materials}

Data included in article. Declaration of interest's statement Consent for publication

Not applicable

\section{Competing interests}

The author declares that he has no competing interests.

\section{Additional information}

No additional information is available for this paper.

\section{Acknowledgements}

The authors would like to thank two anonymous reviewers for their constructive comments on the manuscript.

\section{References}

Abril, A., Bucher, E.H., 2001. Overgrazing and soil carbon dynamics in the western Chaco of Argentina. Applied Soil Ecology 16, 243-249.

Aguiar, A.C.F., Bicudo, S.J., Sobrinho, J.R.S.C., et al., 2010. Nutrient recycling and physical indicators of an alley cropping system in a sandy loam soil in the 
pre-Amazon region of Brazil. Nutrient Cycling in Agroecosystems 86, 189-198.

Aulakh, M.S., 2011, Integrated soil tillage and nutrient management - the way to sustain crop production, soil-plant animal-human health, and environment. Journal of Indian Society of Soil Science 59 Supplement: S23-S34.

Bekele, W. (2003) Economics of Soil and Water Conservation: Theory and Empirical Application to Subsistence Farming in the Eastern Ethiopian Highlands. Doctoral thesis, Dept. of Economics, Acta Universitatis agriculturae Sueciae. Agraria vol. 411.

Boffa, M.B., Reid, T.S., Joo, E., Nesheim, M.E. and Koschinsky, M.L., 1999. Characterization of the gene encoding human TAFI (thrombin- activable fibrinolysis inhibitor; plasma procarboxypeptidase B). Biochemistry, 38(20), pp.6547- 6558

Buresh, R.J. and Tian, G., 1998. Soil improvement by trees in sub- Saharan Africa. In Directions in Tropical Agroforestry Research (pp. 51-76). Springer, Dordrecht.

Cook, M.I., Beissinger, S.R., Toranzos, G.A. and Arendt, W.J., 2005. Incubation reduces microbial growth on eggshells and the opportunity for trans- shell infection. Ecology Letters, 8(5), pp.532-537.

Degefu T, Wolde-meskel E, Frostegard A (2011). Multilocus sequence analyses reveal several unnamed Mesorhizobium genospecies nodulating Acacia species and Sesbania sesban trees in Southern regions of Ethiopia. Syst. Appl. Microbiol. 34:216-226. doi:10.1016/j.syapm.2010.09.006

Gathumbi, S.M., Cadisch, G. and Giller, K.E., 2002. 15N natural abundance as a tool for assessing N2fixation of herbaceous, shrub and tree legumes in improved fallows. Soil Biology and Biochemistry, 34(8), pp.1059- 1071.

Gete Z., Getachew A., Dejene A. and Shahid R. 2010. A Report on Fertilizer and Soil Fertility.

Heering JH (1995). Botanical and agronomic evaluation of a collection of Sesbania sesban and related perennial species. Doctoral thesis, Wageningen Agricultural University, Wageningen, The Netherlands, p.127.

Hilhorst, R., Fijneman, P., Heering, D., Wolbert, R.B.G., Dekker, M., Van't Riet, K. and Bijsterbosch, B.H., 1992. Protein extraction using reversed micelles. Pure and applied chemistry, 64(11), pp.1765-1770.

Kamara, C.S. and Haque, I., 1992. Faidherbia albida and its effects on Ethiopian highland Vertisols. Agroforestry Systems, 18(1), pp.17-29.
Kanyama-Phiri, G.Y., Snapp, S.S. and Minae, S., 1997. Developing improved organic matter technologies in partnership with smallholder farmers in southern Malawi. In African Crop Science Conference Proceedings (Vol. 3, No. 1, pp. 375-384).

Kwesiga, F., Akinnifesi, F.K., Mafongoya, P.L., McDermott, M.H. and Agumya, A. (2003). Agroforestry Research and Development in Southern Africa During The 1990s: Review and Challenges Ahead. Agroforestry Systems 59: 173186, 2003.

Kwesiga, F., Franzel. S., Place, F., Phiri, D., and Simwanza, C.P. (1999). Sesbania sesban Improved Fallows in Eastern Zambia: The inception, development and farmer Enthusiasm. Agroforestry Systems 47: 49-66, 2003

Lal, R., 2007. Carbon sequestration. Philosophical Transactions of the Royal Society B: Biological Sciences, 363(1492), pp.815-830.

Mafongoya, P.L., Bationo, A., Kihara, J. and Waswa, B.S., 2006. Appropriate technologies to replenish soil fertility in southern Africa. Nutrient Cycling in Agroecosystems, 76(2-3), pp.137-151.

Mafongoya, P.L., Kuntashula, E. and Sileshi, G., 2006. Managing soil fertility and nutrient cycles through fertilizer trees in southern Africa. Biological Approaches to Sustainable Soil Systems, Taylor \& Francis, pp.273-289.

Mani RP, Pandey A, Goswami S, Tripathi P, Kumudhavalli V, Singh AP (2011). Phytochemical Screening and In- vitro Evaluation of Antioxidant Activity and Antimicrobial Activity of the Leaves of Sesbania sesban (L) Merr. Free Radic. Antioxidants, 3(1):66-69. doi:10.5530/ax.2011.3.9.

Nigussie, Z. and Alemayehu, G., 2013. Sesbania sesban (L.) Merrill: Potential uses of an underutilized multipurpose tree in Ethiopia. African Journal of Plant Science, 7(10), pp.468-475.

Orwa C, Mutua A, Kindt R, Jamnadass R, Simons A (2009). Agroforestree Database: a tree reference and selection guide version 4.0 (http://www.world agroforestry. org/a f/treedb/)

Pandhare RB, Sangameswaran B, Mohite PB, Khanage SG (2011). Antidiabetic Activity of Aqueous Leaves Extract of Sesbania sesban (L.) Merr. in Streptozotocin Induced Diabetic Rats. Avicenna J. Med. Biotech. 3(1):37-43.

Patra AK, Chhonkar PK, Khan MA (2006). Effect of green manure Sesbania sesban and nitrification inhibitor encapsulated calcium carbide (ECC) on soil mineral-N, enzyme activity and nitrifying organisms in a rice- wheat cropping system. Eur. J. 
Soil Biol. 42:173-

doi:10.1016/j.ejsobi.2005.12.007.

Roger, P.A. and Ladha, J.K., 1992. Biological N 2 fixation in wetland rice fields: Estimation and contribution to nitrogen balance. In Biological Nitrogen Fixation for Sustainable Agriculture (pp. 41-55). Springer, Dordrecht.

Sharma, P., McQuaid, K., Dent, J., Fennerty, M.B., Sampliner, R., Spechler, S., Cameron, A., Corley, D., Falk, G., Goldblum, J. and Hunter, J., 2004. A critical review of the diagnosis and management of Barrett's esophagus: the AGA Chicago Workshop. Gastroenterology, 127(1), pp.310-330.
Yamoah, C.F. and Getahun, A. (1989) Alley cropping and crop yield enhancement with Sesbania. In: Macklin, B. and Evans, D.O. (eds), Perennial Sesbania Species in Agroforestry Systems. Proceedings of an international workshop at ICRAF Nairobi, Kenya. NFTA Special Publication 90-01, pp. 109-122.

Yang B, Shu WS, Ye ZH, Lan CY, Wong MH (2003). Growth and metal accumulation in vetiver and two Sesbania species on lead/zinc mine tailings. Chemosphere 52:1593-1600. doi:10.1016/S00456535(03)00499-5.

\section{How to cite this article:}

Sissay Dessalgn and Addisu Wolde. 2021. Role of Sesbania sesban (L.) Merrill for Soil Fertility Improvement in Ethiopia: A Review. Int.J.Curr.Res.Aca.Rev. 9(01), 81-85.

doi: https://doi.org/10.20546/ijcrar.2021.901.007 